\title{
Parallel Sessions and speakers
}

\section{Wednesday 14 September 2011}

\begin{tabular}{|c|c|}
\hline 10:00-18:00 & Registration (Rootes Building) \\
\hline 12:30-13:45 & $\begin{array}{l}\text { Buffet lunch for free place recipients, invited speakers, SSM National \& ECR Committees and local organising committee (Ramphal Building } \\
\text { Room 2:41) }\end{array}$ \\
\hline $13: 30-14: 15$ & Welcome (Ramphal Lecture Theatre) \\
\hline 14:15-15:00 & $\begin{array}{l}\text { Cochrane lecture (Ramphal Lecture Theatre) } \\
\text { Professor Peter Groenewegen: Strengthening primary care in weak primary health care systems }\end{array}$ \\
\hline :00-15:30 & Refreshments and exhibition / poster viewing (Ramphal Building) \\
\hline
\end{tabular}

\begin{tabular}{|c|c|c|c|c|c|}
\hline $\begin{array}{l}\text { Parallel } \\
\text { Session A }\end{array}$ & $\begin{array}{l}\text { R0.21 } \\
\text { Parenting }\end{array}$ & $\begin{array}{l}\text { R0.12 } \\
\text { Health services research and } \\
\text { policy }\end{array}$ & $\begin{array}{l}\text { R0.14 } \\
\text { Pregnancy and postnatal } \\
\text { health }\end{array}$ & $\begin{array}{l}\text { R1.13 } \\
\text { Social and environmental } \\
\text { determinants }\end{array}$ & $\begin{array}{l}\text { R1.15 } \\
\text { Physical activity and } \\
\text { travel }\end{array}$ \\
\hline $15: 30-15: 50$ & $\begin{array}{l}\text { The development of two } \\
\text { postnatal health instruments: } \\
\text { one for mothers (M-PHI), } \\
\text { one for fathers (F-PHI), to } \\
\text { measure health during the } \\
\text { first year of parenting } \\
\text { CJ Morrell et al OP1 }\end{array}$ & $\begin{array}{l}\text { Policy formulation in the health } \\
\text { system: a case study of the } \\
\text { Expert Advisory Group for } \\
\text { Diabetes S Mc Hugh et al OP5 }\end{array}$ & $\begin{array}{l}\text { \#Why do women attend } \\
\text { late for antenatal booking? } \\
\text { A qualitative interview } \\
\text { study exploring the } \\
\text { perspectives of service } \\
\text { users and stakeholders } \\
\text { GL Jones et al OP9 }\end{array}$ & $\begin{array}{l}\text { Determinants of mental } \\
\text { health and wellbeing in } \\
\text { low income communities: } \\
\text { a multilevel approach } \\
\text { examining individual } \\
\text { and neighbourhood } \\
\text { characteristics } \\
\text { G Phillips et al OP13 }\end{array}$ & $\begin{array}{l}\text { Active travel in children } \\
\text { and its relationship to } \\
\text { overall activity levels } \\
\text { MA Roth et al OP17 }\end{array}$ \\
\hline 15:55-16:15 & $\begin{array}{l}\text { Systematic review of } \\
\text { parenting programs for } \\
\text { preterm and low birth } \\
\text { weight infants on enhancing } \\
\text { parent-infant interaction by } \\
\text { improving parental sensitivity } \\
\text { A Underdown et al OP2 }\end{array}$ & $\begin{array}{l}\text { Assessing the evaluability } \\
\text { of complex public health } \\
\text { interventions: five questions } \\
\text { for researchers, funders and } \\
\text { policymakers } \\
\text { D Ogilvie et al OP6 }\end{array}$ & $\begin{array}{l}\text { Trends in postpartum } \\
\text { haemorrhage in Ireland: } \\
\text { an eleven-year population- } \\
\text { based cohort study } \\
\text { JE Lutomski et al OP10 }\end{array}$ & $\begin{array}{l}\text { A good place for bringing } \\
\text { up children? Mother's } \\
\text { neighbourhood perceptions } \\
\text { and children's behavioural } \\
\text { development in the } \\
\text { Millennium Cohort Study } \\
\text { A Scheiwe et al OP14 }\end{array}$ & $\begin{array}{l}\text { Day length and weather } \\
\text { effects on children's } \\
\text { physical activity and } \\
\text { participation in play, sports } \\
\text { and active travel } \\
\text { J Paskins et al OP18 }\end{array}$ \\
\hline $16: 20-16: 40$ & $\begin{array}{l}\text { Exposure to sexually explicit } \\
\text { visual media and sexual } \\
\text { debut at age } 15 \\
\text { C Nixon et al OP3 }\end{array}$ & $\begin{array}{l}\text { "Surely there must be more } \\
\text { evidence ... !" Reviewing } \\
\text { literature to support the } \\
\text { development of evidence-based } \\
\text { public health guidance by the } \\
\text { National Institute for Health } \\
\text { and Clinical Effectiveness } \\
\text { N Payne et al OP7 }\end{array}$ & $\begin{array}{l}\text { Effectiveness of training in } \\
\text { motivational interviewing } \\
\text { in influencing smoking } \\
\text { cessation in pregnant } \\
\text { and post-partum women } \\
\text { in lower socio-economic } \\
\text { groups C Hayes et al OP11 }\end{array}$ & $\begin{array}{l}\text { Self-rated health and area } \\
\text { deprivation: exploring a } \\
\text { differential association } \\
\text { among white British and } \\
\text { ethnic minority people in } \\
\text { England } \\
\text { L Becares et al OP15 }\end{array}$ & $\begin{array}{l}\text { How and why do people } \\
\text { commute by car? A mixed- } \\
\text { methods investigation } \\
\text { A Goodman et al OP19 }\end{array}$ \\
\hline $16: 45-17: 05$ & $\begin{array}{l}\text { Longitudinal associations } \\
\text { between screen time and } \\
\text { children's behavioural and } \\
\text { emotional adjustment at } \\
\text { age } 7 \\
\text { A M Parkes et al OP4 }\end{array}$ & $\begin{array}{l}\text { Barriers to intersectoral } \\
\text { working to improve health: a } \\
\text { qualitative study } \\
\text { DC Taylor-Robinson et al OP8 }\end{array}$ & $\begin{array}{l}\text { \#The health of postnatal } \\
\text { women's partners up to } \\
18 \text { months after their baby } \\
\text { was born: a longitudinal } \\
\text { survey alongside a } \\
\text { randomised controlled trial } \\
\text { CJ Morrell et al OP12 }\end{array}$ & $\begin{array}{l}\text { Associations between } \\
\text { sedentary behaviour and } \\
\text { cardiovascular, hemostatic } \\
\text { and diabetic markers in mid- } \\
\text { adult life ( } 45 \text { years) } \\
\text { SM Pinto Pereira et al OP16 }\end{array}$ & $\begin{array}{l}\text { Is a change in mode of } \\
\text { travel to school associated } \\
\text { with a change in overall } \\
\text { physical activity levels } \\
\text { in children? Longitudinal } \\
\text { results from the SPEEDY } \\
\text { study } \\
\text { L Smith et al OP20 }\end{array}$ \\
\hline
\end{tabular}

$17: 15-18: 15$ 19:00-20:30

Conference reception (Butterworth Hall, Warwick Arts Centre)

\section{Thursday 15 September 2011}

\begin{tabular}{|c|c|c|c|c|c|}
\hline $\begin{array}{l}\text { Parallel } \\
\text { Session B }\end{array}$ & $\begin{array}{l}\text { R0.21 } \\
\text { Cardiovascular disease } \\
\text { and mortality }\end{array}$ & $\begin{array}{l}\text { R0.12 } \\
\text { Health services research } \\
\text { and clinical issues }\end{array}$ & $\begin{array}{l}\text { R0.14 } \\
\text { Mental health and } \\
\text { wellbeing }\end{array}$ & $\begin{array}{l}\text { R1.13 } \\
\text { Obesity and diet }\end{array}$ & $\begin{array}{l}\text { R1.15 } \\
\text { Innovative methods }\end{array}$ \\
\hline $09: 00-09: 20$ & $\begin{array}{l}\text { \# Modelling coronary heart } \\
\text { disease mortality in Northern } \\
\text { Ireland between } 1987 \\
\text { and } 2007 \\
\text { J Hughes et al OP21 }\end{array}$ & $\begin{array}{l}\text { Prevalence of chronic kidney } \\
\text { disease in England: findings } \\
\text { from the } 2009 \text { Health Survey } \\
\text { for England } \\
\text { P Roderick et al OP26 }\end{array}$ & $\begin{array}{l}\text { What factors are associated } \\
\text { with a validated measure } \\
\text { of mental wellbeing in } \\
\text { the general population in } \\
\text { Coventry? A stratified } \\
\text { random cross sectional } \\
\text { survey } \\
\text { R Putzet al OP31 }\end{array}$ & $\begin{array}{l}\text { Adiposity and } \\
\text { cardiometabolic risk } \\
\text { markers among Indian } \\
\text { children: comparison with } \\
\text { Indian and white European } \\
\text { children in the UK } \\
\text { CM Nightingale et al OP36 }\end{array}$ & $\begin{array}{l}\text { Testing life course models } \\
\text { to investigate the effect } \\
\text { of socioeconomic position } \\
\text { on crystallized cognitive } \\
\text { function in older age, } \\
\text { accounting for missing } \\
\text { data } \\
\text { R Landy et al OP41 }\end{array}$ \\
\hline $09: 25-09: 45$ & $\begin{array}{l}\text { Explaining recent } \\
\text { coronary heart disease } \\
\text { mortality trends in } \\
\text { England by socioeconomic } \\
\text { circumstances, 2000-2007 } \\
\text { M Bajekal et al OP22 }\end{array}$ & $\begin{array}{l}\text { Diagnostic accuracy of } \\
\text { clinical tests for subacromial } \\
\text { impingement syndrome (SIS): } \\
\text { a systematic review and meta- } \\
\text { analysis } \\
\text { M Alqunaee et al OP27 }\end{array}$ & $\begin{array}{l}\text { Give my head peace: } \\
\text { psychotropic drug uptake } \\
\text { around the 'peace-lines' in } \\
\text { Northern Ireland } \\
\text { D 0'Reilly et al OP32 }\end{array}$ & $\begin{array}{l}\text { Adiposity has differing } \\
\text { associations with coronary } \\
\text { heart disease incidence and } \\
\text { mortality in the Scottish } \\
\text { Health Survey Cohort: Cross } \\
\text { sectional surveys with } \\
\text { follow-up } \\
\text { JW Hotchkiss et al OP37 }\end{array}$ & $\begin{array}{l}\text { Service users' experiences } \\
\text { of a physical activity and } \\
\text { lifestyle intervention for } \\
\text { people with severe mental } \\
\text { illness: a longitudinal } \\
\text { qualitative study } \\
\text { A Alba et al OP42 }\end{array}$ \\
\hline
\end{tabular}




\begin{tabular}{|c|c|c|c|c|c|}
\hline $\begin{array}{l}\text { Parallel } \\
\text { Session B }\end{array}$ & $\begin{array}{l}\text { R0.21 } \\
\text { Cardiovascular disease } \\
\text { and mortality }\end{array}$ & $\begin{array}{l}\text { R0.12 } \\
\text { Health services research } \\
\text { and clinical issues }\end{array}$ & $\begin{array}{l}\text { R0.14 } \\
\text { Mental health and } \\
\text { wellbeing }\end{array}$ & $\begin{array}{l}\text { R1.13 } \\
\text { Obesity and diet }\end{array}$ & $\begin{array}{l}\text { R1.15 } \\
\text { Innovative methods }\end{array}$ \\
\hline 09:50-10:10 & $\begin{array}{l}\text { Potential cardiovascular } \\
\text { mortality reductions in Ireland } \\
\text { associated with specific food } \\
\text { policy options } \\
\text { C O'Keeffe et al OP23 }\end{array}$ & $\begin{array}{l}\text { Does the performance of } \\
\text { mammography readers in the } \\
\text { NHSBSP vary? And how much } \\
\text { does this matter? } \\
\text { S Taylor-Phillips et al OP28 }\end{array}$ & $\begin{array}{l}\text { The use of communication } \\
\text { technologies for the } \\
\text { engagement of young adults } \\
\text { and adolescents in mental } \\
\text { health care } \\
\text { S Martin et al OP33 }\end{array}$ & $\begin{array}{l}\text { Short and medium term } \\
\text { effects of a community-based } \\
\text { intervention to address social } \\
\text { inequalities in health S Visram } \\
\text { et al OP38 }\end{array}$ & $\begin{array}{l}\text { What is research? Views of } \\
\text { minority groups } \\
\text { G Plumridge et al OP43 }\end{array}$ \\
\hline
\end{tabular}

10:15-10:35 Trends and inequalities in cardiovascular disease mortality in Scotland, 1974-2009

CA Davies et al OP24

$10: 40-11: 00$

\#An investigation through microsimulation of the inequities in Coronary Heart Disease (CHD) mortality and morbidity in Wales

WJ Watkins et al OP25
OEDIPUS: A cluster randomised trial of education for South Asians with asthma, and their primary and secondary care physicians, to reduce unscheduled care SJC Taylor et al OP29

Pharmacist-led management of chronic pain in primary care: the PIPPC study R Holland et al OP30

S Martin et al OP33

Investigating the effects labour market position on minor psychiatric morbidity across the business cycle: longitudinal analysis of the British Household Panel Survey, 1991-2007

E Flint et al OP34

Vitamin D to reduce depressive symptoms: a systematic review CMJ Day et al OP35

Psychological distress and Body Mass Index: comorbidity and direction of associations over the life-course

MCG Geoffroy et al OP39

Associations between adolescent obesity and both individual and group-level social status HN Sweeting et al OP40
Clinical versus economic interpretations of RCT results - mixed messages? D McKell-Redwood et al OP44

Timely and complete publication of economic evaluations alongside randomised controlled trials

J Thorn et al 0P45

11:00-11:40 Refreshments and exhibition / poster viewing (Ramphal Building)

\begin{tabular}{|c|c|c|}
\hline $\begin{array}{l}\text { Parallel Session } \\
\text { C }\end{array}$ & $\begin{array}{l}\text { Ro.21 } \\
\text { Cardiovascular disease and } \\
\text { inequalities }\end{array}$ & $\begin{array}{l}\text { R0.12 } \\
\text { Social determinants and } \\
\text { mortality }\end{array}$ \\
\hline $11: 40-12: 00$ & $\begin{array}{l}\text { Reducing socioeconomic } \\
\text { inequality in coronary disease } \\
\text { treatments: the NHS finally } \\
\text { triumphs? } \\
\text { NM Hawkins et al OP46 }\end{array}$ & $\begin{array}{l}\text { Socio-demographic diversity } \\
\text { and unexplained variation in } \\
\text { death rates between the most } \\
\text { deprived areas in Britain } \\
\text { H Tunstall et al OP50 }\end{array}$ \\
\hline
\end{tabular}

NM Hawkins et al OP46 H Tunstall et al OP50

12:05-12:25 Uptake of the NHS Health Checks programme in a deprived, culturally diverse setting: cross sectional study ARH Dalton et al OP47

Socio-economic status and mortality from cardiovascular disease among people with

Type 2 diabetes in Scotland (2001-2007)

J Walker OP51
$12: 30-12: 50$

Influence of the daily consumption of vegetables and fruits on arterial dysfunction in patients with rheumatoid arthritis: a crosssectional study employing pulse wave analysis MA Crilly et al OP48

12:55-13:15 Ethnic differences in carotid intima media thickness and carotid-femoral pulse wave velocity are present in UK children PH Whincup et al OP49
Socio-economic position over the life course and allcause, circulatory diseases, and neoplasms mortality in adulthood and old age: results from a Swedish birth cohort B De Stavola et al OP52

\#The effect of socioeconomic status on mortality in the critically ill: a national data linkage study NI Lone et al OP53
R0.14 R1.13 R1.15 Gender

How robust is the evidence of an emerging or increasing female excess in physical morbidity rates between childhood and adolescence? Results of a systematic literature review

K Hunt et al OP54

Are there gender differences in the relative predictive ability of lung function in all-cause mortality? Findings from 13 years of follow up in the Scottish Health Surveymortality linked datasets (1995 to 2008)

L Gray et al 0P55

Failing to meet

expectations: the meaning of Intimate Partner Violence for Pakistanis PA Ali et al 0P56

Inequalities in eating behaviour of 11- 15 year old boys and girls in Scotland, 2002-2010 KA Levin OP57 children using functional analysis of variance F Sera et al 0P59
Who wears an accelerometer? Correlates of adherence to wearing an accelerometry motion sensor: the 2008 Health Survey for England JS Mindell et al OP60

Validation of the Phenotype of Frailty measurement in the Whitehall II study $\mathrm{K}$ Bouillon et al OP61
Methods and measurement Infant and child health

\#Associations of mortality Are children born after

rates with height using son's infertility at increased risk height as an instrumental of asthma? variable

C Carson et al OP62 data from 7-year old British a few weeks premature are more likely to have poorer school performance than those born at full term MA Quigley et al OP63

Traveller infant mortality is persistently higher than the general population in the All Ireland Traveller Birth Cohort study NA Hamid et al 0P64

Birth size differences between white British and Pakistani origin infants by generation: results from the Born in Bradford cohort study

DA Lawlor et al 0P65
13:15-14:00

\section{Workshops}

14:00-17:00
Packed or sit down lunch (Rootes Building)

Room Ro.12

Mental wellbeing
Room R0.14

Aspirin in perspective
Room R1.13

ECR showcase and networking

\begin{tabular}{|c|c|c|c|c|c|}
\hline $\begin{array}{l}\text { Outings } \\
14: 00-17: 00\end{array}$ & Compton Verney & Kenilworth Castle & Kenilworth walk & $\begin{array}{l}\text { Warwick Campus } \\
\text { sculpture walk }\end{array}$ & $\begin{array}{l}\text { Explore } \\
\text { Coventry }\end{array}$ \\
\hline $18: 30$ & Coach travel to Di & ner (Coaches depart from Ramphal Building) & & & \\
\hline 19:00-22:00 & Conference Dinne & & & & \\
\hline $22: 00-23: 00$ & $\begin{array}{l}\text { Ceilidh (Assembly } \\
\text { Coaches depart fo }\end{array}$ & $\begin{array}{l}\text { Loms of the Pump Room, Leamington Spa) } \\
\text { Warwick campus 22:30-23:30 }\end{array}$ & & & \\
\hline
\end{tabular}


Friday 16 September 2011

\begin{tabular}{|c|c|c|c|c|c|}
\hline $\begin{array}{l}\text { Parallel } \\
\text { Session D }\end{array}$ & $\begin{array}{l}\text { R0.21 } \\
\text { Birth cohort and lifecourse }\end{array}$ & $\begin{array}{l}\text { R0.12 } \\
\text { Social determinants and } \\
\text { child health }\end{array}$ & $\begin{array}{l}\text { R0.14 } \\
\text { Ageing and older } \\
\text { people }\end{array}$ & $\begin{array}{l}\text { R1.13 } \\
\text { International health }\end{array}$ & $\begin{array}{l}\text { R1.15 } \\
\text { Physical activity and } \\
\text { environment }\end{array}$ \\
\hline 09:00-09:20 & $\begin{array}{l}\text { \#Clinical problems in a post } \\
\text { war British cohort reaching } \\
\text { retirement: evidence from } \\
\text { the first British Birth Cohort } \\
\text { Study } \\
\text { MB Pierce et al OP66 }\end{array}$ & $\begin{array}{l}\text { Born into adversity; the } \\
\text { intergenerational transmission } \\
\text { of psychological morbidity in } \\
\text { second generation Irish children } \\
\text { living in Britain } \\
\text { J Das-Munshi et al OP70 }\end{array}$ & $\begin{array}{l}\text { Does the use of } \\
\text { psychotropic medications } \\
\text { increase on entering a } \\
\text { care home? A prospective } \\
\text { pharmacoepidemiological } \\
\text { study } \\
\text { A Maguire et al OP74 }\end{array}$ & $\begin{array}{l}\text { The geography of HIV/AIDS } \\
\text { infection in Botswana } \\
\text { NB Kandala et al OP78 }\end{array}$ & $\begin{array}{l}\text { Choice preference and } \\
\text { physical activity behaviour } \\
\text { WG Hutchinson et al OP82 }\end{array}$ \\
\hline 10:15-10:35 & $\begin{array}{l}\text { Associations between birth } \\
\text { weight and body composition } \\
\text { in later life: preliminary } \\
\text { findings from a British birth } \\
\text { cohort study } \\
\text { D Bann et al OP69 }\end{array}$ & $\begin{array}{l}\text { The secondary-school 'market' } \\
\text { and young people's health: } \\
\text { qualitative case-study research } \\
\text { in seven English secondary- } \\
\text { schools } \\
\text { A Fletcher et al OP73 }\end{array}$ & $\begin{array}{l}\text { \#Diet in childhood and } \\
\text { adulthood and physical } \\
\text { performance in old age: } \\
\text { findings from the Boyd Orr } \\
\text { and Caerphilly cohorts } \\
\text { K Birnie et al OP77 }\end{array}$ & $\begin{array}{l}\text { Treatment gap in depression } \\
\text { J Twynam-Perkins et al } \\
\text { OP81 }\end{array}$ & $\begin{array}{l}\text { \#Does participating in } \\
\text { physical activity in outdoor } \\
\text { natural environments have } \\
\text { a greater effect on physical } \\
\text { and mental wellbeing that } \\
\text { physical activity indoors? } \\
\text { A systematic review } \\
\text { J Thompson et al OP85 }\end{array}$ \\
\hline 12:20-13:05 & \multicolumn{5}{|c|}{$\begin{array}{l}\text { Pemberton Lecture (Ramphal Lecture Theatre) } \\
\text { Professor Debbie Lawlor: Developmental overnutrition - an old hypothesis with new importance? }\end{array}$} \\
\hline 13:05-13:20 & \multicolumn{5}{|c|}{ Awards and closing remarks } \\
\hline 13:30 & \multicolumn{5}{|c|}{ Packed lunch should be collected from Rootes building } \\
\hline
\end{tabular}

\#High Scoring abstract 